\title{
Analysis of Decision, Plans, and Actions for the Containment of COVID-19 in Indonesia
}

\author{
Saut Sagala* \\ School of Architecture, Planning and \\ Policy Development \\ Bandung Institute of Technology \\ Bandung, Indonesia \\ saut.sagala@gmail.com \\ Danang Azhari \\ Disaster and Climate Resilience \\ Resilience Development Initiative \\ Bandung, Indonesia \\ dana.azhari@rdi.or.id
}

\author{
Arief Rosyidie \\ School of Architecture, Planning and \\ Policy Development \\ Bandung Institute of Technology \\ Bandung, Indonesia \\ ariefrosyidie@yahoo.com \\ Salma N. Annisa \\ Children, Social Welfare and Health \\ Resilience Development Initiative \\ Bandung, Indonesia \\ salma.annisa@rdi.or.id
}

\author{
Amesta K. Ramadhani \\ Disaster and Climate Resilience \\ Resilience Development Initiative \\ Bandung, Indonesia \\ amesta.kartika@rdi.or.id
}

Rufaida N. Vicri

Children, Social Welfare and Health

Resilience Development Initiative

Bandung, Indonesia

rufaida.nurul@rdi.or.id

\author{
Ichsan Hafiz Loeksmanto \\ Renewable Energy and Emission \\ Reduction \\ Resilience Development Initiative \\ Bandung, Indonesia \\ Ichsan.hafiz@rdi.or.id
}

\author{
Muhammad Dimas Mahardika \\ Faculty of Engineering \\ Gadjah Mada University \\ Yogyakarta, Indonesia \\ dimas.mahardika99@gmail.com
}

\begin{abstract}
The emergence and spread of the novel Coronavirus have placed a spotlight on the critical role of effective governance in managing a health crisis. In Indonesia, policymakers are continuously creating new ways to respond to the pandemic in order to manage its wide-ranging impacts. Similar to the rest of the world the highly heterogeneous impact of COVID-19 put the Indonesia Government in a difficult position. The government confined in a double crisis dilemma of health and the economy. As the crisis wreak havoc on Indonesia economy, the government has concentrated the countermeasures in dealing with the economic impact. And thus, this paper takes an in-depth look at Indonesia's COVID19 governance, as well as the rationale on why Indonesia seemingly prioritizes the economy with economy-oriented such as the social mobility policy in June. As a result, entering the sixth month of the pandemic, Indonesia continues to struggle to control rapid virus transmission. Realizing the severe health consequences, as well as a backlash, of downplaying the outbreak, the central government has stated that public health is instrumental and thus measures that to be taken will be based on the current health concerns. Nonetheless, in practice, the policies are still oriented towards economic recovery. Hence, this paper aims to answer the following research question: "What are the reasons for Indonesia's ambivalent strategy in handling COVID-19?" this paper used qualitative analysis and the assessment utilized a desk review. The result shows that severe economic consequences and Indonesia's limited capacity in providing assistance have forced Indonesia to reopen the economy to prevent large-scale financial crises. Practical implications of the findings and discussion can be treated as reflection and lessons learned to improve response strategy to the existing and future large-scale outbreak.
\end{abstract}

Keywords-Indonesia, COVID-19, governance, government, policy

\section{INTRODUCTION}

As of 20th of September 2020, the transmission rate of the Novel Coronavirus (COVID-19) in Indonesia has not been slowing down - with COVID-19 confirmed cases reaching 244,676 , an increase of cases of 3,989 people and 105 additional deaths for the last 24 hours - totaling the number of deaths nationwide to 9,533 [1]. Fig. 1 shows the cases perday in Indonesia has been increasing exponentially since April 2020. Although since July 2020 Indonesia's executive government branch has repeatedly stated that Indonesia needs to 'flatten the curve' [2], the complexity of this pandemic has undoubtedly raised the dilemma between prioritizing public health or ensuring the country's financial security in spite of the life loss.

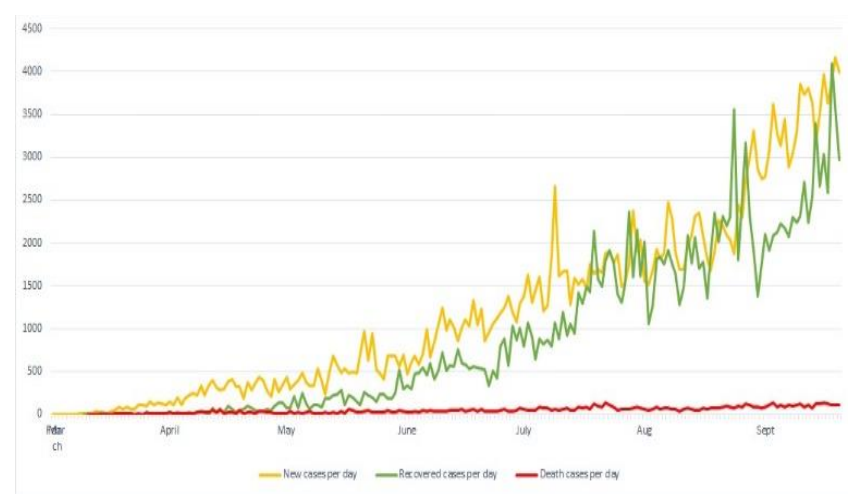

Fig. 1. Daily COVID-19 cases in Indonesia as per April, 2020, Based on the Humanitarian Data Exchange (HDX), Indonesia: Coronavirus (COVID19) Subnational Cases 
SMERU [3] has stated that disease suppression policies would indeed save lives, however, it also comes with the risk of economic instability. Various studies have projected that Indonesia's economic annual growth might be slowed down between 1 and 4 percent compared to its baseline of $5 \%$ of annual growth in 2020 - as a result of this macroeconomic condition, it was also projected that 1.3 million more people will be pushed into poverty, and 8.5 people will be driven into 'poor' livelihood condition category [3].

As Indonesia is the fourth most populous country worldwide, it is predicted to suffer greatly and in a longer time period if compared with other less populous countries. Previously, when COVID-19 was prominently rampaging throughout China in December 2019-February 2020, Indonesia reported zero cases of infection, while as of March 2020 the country only reported two first cases of the virus. In April the number of cases rose significantly to 1790 confirmed cases and 170 deaths. In March 2020, the Government of Indonesia (GoI) started to realize the direness of the situation and since then had implemented various policies and actions [4]. However, it was previously identified that response measures by the GoI put less emphasis on cross-sectors and cross-government levels but most of the response efforts focus mainly on those made by the national government [5].

Considering the constant increase in the number of cases and deaths along with the increasingly severe impact of COVID-19 towards people's livelihoods, public pressure towards the GoI is increasingly mounting [6], demanding the GoI to better respond to the pandemic-along with demands for improvements from what has been previously seen as inadequate due to complications in bureaucratic processes, especially in terms of early response [7].

According to the Ministry of Finance, the GoI top priorities in tackling the pandemic along with its economic impact includes allocating support towards the healthcare sector, as well as strengthening social safety nets and salvaging business sectors [8]. Economic stimulus packages have been channeled through the enactment of several key policies [9]. Along with the economic stimulus packages, the GoI has also implemented Large-Scale Social Restriction measures through GR No.21/2020 - to limit activities and human-to-human transmission by limiting religious activities and activities in public spaces or facilities, as well as suspending school and workplace activities.

Stricter social restriction measures were previously implemented in several regions with a high number of cases categorized as 'red zones' since April 2020, and it was identified that as of June 2020, 37 regencies and cities in 19 provinces previously categorized as 'yellow' zones have succeeded in becoming 'green zones'. Since then, most of the regions in Indonesia has lifted its social restriction and transitioned into 'new normal' or 'PSBB Transisi', which implements a less stringent social restriction although with full implementation of health protocols [10]. However, this ease of social restrictions has yielded into another significant increase in terms of infection rates since August - forcing the GoI to hit the brakes especially in zones with exceptionally high cases such as Jakarta City, as one of the epicenters.

The return of infection rate spikes in Indonesia in late 2020 signals the need for reflection and evaluation for the GoI's efforts in handling the health crisis — which is exactly the main aim of this paper. This paper aims to understand the reason for Indonesia's ambivalent strategy in handling COVID-19 by scrutinizing key aspect related to policies, plans, and actions, without discrediting the initiatives done, but providing insight towards key lessons learned for Indonesia moving forward to further flatten the COVID-19 curve.

\section{LITERATURE REVIEW}

\section{A. Public Health Policies}

In terms of public health policies related to financial aspects, Whiteford and Weissman (2017) state that there are seven factors that influence policy, namely the size of the health burden arising from an illness or health condition, the availability of cost-effective care, the ability of the private market to provide efficient health care for the condition, catastrophic costs associated with treating the condition, negative externalities associated with non-treatment, and "rescue rules [11]."

The first factor, namely health burden is one of the most important and syringes. In addition, the size of the burden must also consider the cost so that the intervention factor of cost ineffectiveness will influence policy. The third factor that is still related is the private market. This does not mean that subsidies are the government's solution to the second factor. An effective private market will make the government unnecessary to provide subsidies [12], [13]. Fourth, the government tends to provide subsidies for large medical expenses. Fifth, the government is afraid of negative perceptions that do not provide proper health services. Sixth, the government tends to be involved in providing services when the disease is in accordance with the rules for safety while the last is the government considering whether regulations or policies are really needed.

\section{B. Factors that Influence Policy Making}

Public policy can be defined-appropriately-as clearcut resource allocation delivered by projects and programs with the aim of response to perceived public challenges and problems requiring government action for their solution. The extent and substance of public policies may differ from government to government, which also depends on the system of government and its ideologies implemented [14].

The research field of political and social sciences have developed various theories, models, and approaches to conduct an analysis of public policy. The systems theory which was developed by David Easton in 1953 is one of those theories. According to this model, public policy is the response of the political system to demands from its environment. In a more detailed manner, this model theorized that the political system receives inputs from its environment and transformed them into outputs. The inputs are in the form of demands from groups or individuals for specific policy outcomes; and the policy outcomes can be seen as a determination of societal values and allocation of resources. Between the outputs and inputs, there exists a feedback loop that was formed after a series of decision iterations [14].

One of the branches of social science that can be seen as very influential towards the art of policy making is economics. Hirschmand and Berman pointed out that existing researches indicate that the influence of economics is conciliated by local circumstances and meso-level social structures, and those 
conciliations trickle through channels that are indirect [15]. They also suggested that to elucidate those economic influences, there are three sites of analysis appropriate: the broad professional authority of economics, the institutional position of economists in government, and the role of economics in the cognitive infrastructure and policy making (which involve the diffusion of economic styles of reasoning and the establishment of economic policy devices). In policy making, policymakers also make use of economic policy devices that help them make decisions through economic lenses. Tools such as cost-benefit analysis help policymakers to produce information that allows them to see economic variables that should be taken into account, such as the Gross Domestic Product (GPD), the inflation rate or the unemployment rate.[16][15] Hodgson (1987) argued that the usage of systems approach can be useful in the fields of economics, especially for developing criteria for evaluating the relative advantages and disadvantages of planning and market mechanisms, as well as the performance potential of their combination [17].

In the context of relation between the economy and other sectors, such as public health, McKee and Stuckler (2020) argued that previous crises have demonstrated that an economic crash has grave consequences for public health. However, they also noted that in the COVID-19 pandemic, the world "is entering uncharted territory", and the preservation of public health has to be prioritized thoroughly [18]. The reason why COVID-19 pandemic will have, and has already had, a quite severe economic impact is because countries have structured their societies in manners that make them extremely unprotected. Lin and Meissner (2020) also concluded that COVID-19 pandemic - which they deem as "a common economic and public health shock"-highlighted the significance of economic and public health responses that are coordinated thoroughly [19]. To mitigate the disaster too, a proper analysis of policy spillovers and behavioral responses are needed.

\section{INDONESIA RESPONSE AND MEASURES IN HANDLING THE COVID-19}

\section{A. Early Response to COVID-19}

Reflecting from the early stages of this pandemic, Indonesia has the 'privilege' of low infection rates and even zero cases of COVID-19 throughout January-February 2020. However, reports published later in that period have indicated that zero cases were scientifically improbable and might have been an indication of bad performance in screening and lack of technical skills and facilities to detect and diagnose the virus [4], [20]. Controversies surrounding the eligibility of rapid testing kits widely used since March 2020 was also problematic - since these testing kits were deemed inaccurate and none of the kits had yet passed clinical testing to confirm its accuracy [21]. This issue surrounding testing and rapid tests was the first key obstacle keeping the GoI from getting the necessary information as a baseline for executing proper early response measures [4].

Other than the issue of testing as a main determinant of the performance of early response measures by the GoI, regulatory and institutional response was also seen as insufficient to end the spread of COVID-19 during the initial phase. As an example, the heavily criticized Ministry of Health $(\mathrm{MoH})$ - although was one of the first ministerial level agencies to formally respond to COVID-19, was lacking in terms of preparedness, indicated by gaps in the six building blocks of the health system i.e. access to medicine, health service delivery, workforce, information system, leadership, governance, and health system financing. In addition, there was no clear indication of acceleration in response until the first confirmed cases [4]. Furthermore, lack of testing done during the first half of March 2020 was also an indication of gaps and weakness in infrastructure (i.e. laboratories) and the overall health system [22].

\section{B. Confusing Patchworks of Containment Measures}

The manifestation of a delayed response in handling COVID-19 also includes the lack of clarity in containment measures. In March 2020, Indonesia's President emphasized that all major policies related to COVID-19 must be discussed in advance with the national government in consultation with relevant ministries and the COVID-19 Task Force. The President also asserted that regional lockdown and quarantine policies or decisions belong to the national government - not the local government [23]. Moreover, the dilemma between implementing and enforcing lockdown policies and Indonesia's economic interest was in the forefront cause of the delayed response, albeit it is understandable that a selection of one between both was complex and difficult.

However, it can be reflected that one of the key aspects which hinders effective and timely response by local governments is the complexity of Indonesia's bureaucratic process. Despite the urgency, PP No. 21/2020 on Large-scale Social Restriction (PSBB) mandated local governments to submit a proposal for PSBB prior to its implementation. although PP 21/2020 in itself took some time for its enactment process and had only been issued on March 31st. As a result, the reluctance and lack of timeliness from regional governments to implement large-scale legally enforced social restriction measures e.g. in DKI Jakarta, West Java Province, Bandung City, Depok City, etc. was exacerbated by the lack of legal directives from the national government to enforce PSBB and a time-consuming process of conducting regional or city level risk assessments to support the proposals that were later submitted to the National Government. Furthermore, the effectiveness of PSBB itself is questionable, e.g. inter-city travels remained uninterrupted throughout mid to late 2020. In addition, it must also be noted that due to most Indonesians working in the informal sector, financial stimulus packages must also be disbursed to lower-middle-class citizens especially for those working in the informal sector to incentivize those citizens to limit interactions among social groups [24].

\section{DILEMMA IN PRIORITY: A HEALTH VS WEALTH TRADE-} OFF

\section{A. Unprecedented Socioeconomic Impact of COVID-19 in Indonesia and How It Influences Decision Making Process}

Drastic deterioration of economic activity putting Indonesia at serious risk of a COVID-19-induced recession. Fiscal stimuli to cushion economic fallout can only do so much during the pandemic. Common measures practiced used by the governments and central banks, such as lowering interest rates or implementing fiscal stimuli have only limited effects, and at most they can only mitigate the effects rather 
than granting full economy protection [18]. The decline in Indonesia's economic performance was due to a contraction in household consumption by 5\% [25]. In retrospect, household consumption was the main contributor to Indonesia's Gross Domestic Product (GDP) until Q1 of 2020, the effect was just enough to set off recession alarms. Entering the sixth month of the outbreaks where COVID-19 cases continue to climb, Indonesia is still hesitant to re-enact lockdown policy. The unwillingness to re-impose lockdown policy may due to fear of economic stagnation and full blown nationwide recession prompted by the lockdown policy, as it curtails economic activities, hence the economic-centric policy [26]. Amidst the health crisis it seems that economy recovery remains the focus of Indonesia. Relaxed PSBB policy in between June and August, and the unwillingness to re-enter lockdown restrictions despite the daily increase of COVID-19 cases across the country evidently become proof that Indonesia is reluctant to shift the gear to public health recovery.

To know the rationale for the policy direction first we should acknowledge that in a double crisis setting the situation is likely to develop very differently between an environment in which a workforce has access to free healthcare and guaranteed income protection than in one in which people are challenged to either go to work when ill or lose their income [18]. In Indonesia, the enactment of social restriction policies has dented business across the country leaving informal workers such as ride-hailing drivers and stress vendors economically vulnerable. Not to mention massive company laid off and furloughed leaving hundreds of thousands lowpaid workers jobless. This particular condition could stir up public unrest. In Ambon dozens of market traders rallied against the implementation of PSBB/lockdown policy in their city [27]. In Jakarta thousands of workers, farmers and street workers demonstrated against Omnibus law and also Corona layoffs [28]. Though, the government has distributed social assistance to mitigate negative economic impact, such measures can only last for a very limited time. In hindsight to re-enact and extend lockdown policy becoming a very difficult choice considering it can provoke large-scale social unrest.

This is where system theory comes into play. Easton D. (1957) illustrates a political system as a complex arrangement of interrelated units, and what keeps the system going are inputs of various kinds. One of Easton's major attributes of political systems are inputs which are divided into two basic kinds: demands and support. Demands are inputs that are being made by individuals or communities within the society with the purpose of satisfying their interest or values. The environment, which where the system rooted, is built with diverse constituent (e.g. as the ecology, economy, culture, personality, social structure, and demography) and each of these integrands of agglomerated arrangement helps to shape the kind of demand entering a political system [29]. In the realm of public policy, the system theory envisages public policy as the response of the political system to demands from its environment [14]. This systemic approach on policy problems would appear to help us better understand Indonesia's ambivalent policy on COVID-19 governance.

As mentioned above we should take account of the situation in Indonesia. As the fourth most populous country, the healthcare budget and economic stimulus package may not be enough to weather the impact of COVID-19 [30]. Even with the ambitious 405 trillion social assistance programs, $87 \%$ residents who have received assistance state that the aid only lasts for only two weeks or less [31]. The assistance may not be enough to cover the loss of income of the lowsocioeconomic status household. Furthermore, Furloughed, as well as massive layoffs only exacerbate the preexisting social vulnerability within the community. These feelings of frustration, injustice and dissatisfaction stemming from the state of economy are expressed through mass protest as seen in Ambon and Jakarta. Protest is used as a tool of aggregate information that can signal citizens private information to the policy maker, who can then choose to use it to select better policies [32]. To system theory these actions can be seen as inputs/ demands from the environment which in accordance to the theory should be converted into extractive, regulative, distributed and symbolic outputs [33]. This brings us to the answer of this paper questions, the ambivalent policy that seemingly prioritizes economy over health is a form of response of the government to the profuse public's demand to return to work and reopen the economy. One can argue that it is the fault of poor governance and inadequate institutional capacity, but we also should not discredit the driving factors that influence the government to take such measures.

\section{B. A Rugged Act of Balancing the Health and Economy}

Our findings suggest that the government of Indonesia continues to face struggle and dilemma in economy and public health safety as the economy slowly and steadily deteriorates into nationwide recession. The so-called "new normal" phase announced in June does seem to reflect the government's tilt towards an economic-centric policy direction rather than focusing on flattening the curve.

Despite a plethora of information showing the government's focus on economic recovery, it does not seem that the government perceives it the same way. On September 26, the President gave a statement in the Presidential Secretariat's YouTube channel that his "government's policy direction while facing the pandemic has always been consistent" as in "handling the public health issues is the foremost priority" [34]. However, he also added that the government continues to focus on economic recovery as well.

This paper does not refute the importance of the economy in a pandemic and public health crisis nor rebuke the government's attempts to manage the health crisis. In fact, studies show that the lockdown and self-isolation policies have effectively inhibited the spread of the coronavirus [35], but in exchange with severe economic implications in which many work activities are forced to stop as workers and consumers are forced to self-isolate, [18], [36], creating major unrest and socioeconomic crisis. For Indonesia, especially, another systemic and financial crisis like what happened in 1998 has to be taken into consideration. Additionally, economic decline itself has an adverse effect on health. A reduction in economic activity reduces the finances available for the public-health countermeasures needed to control the pandemic [18]. Essentially, the relationship between the economy and health is interrelated, not separate [37]. For instance, the government has to ensure the availability of a social safety net to ensure the people could afford basic necessities and health services in times of pandemic. 
Nevertheless, any economic recovery or financial protection programs in times of pandemic would never work at the expense of health safety and the lives of many. Many cases of death have resulted in the collapse of the national industry, an increase in the number of people who have lost their jobs, and health problems for residents due to what is known as a "disease of hopelessness" [38]. Within the government that acts as the formal decision makers, an economic recovery program that supports the small and medium scale enterprises rather than big investors should be devised. The government has allocated IDR 123 trillion to support micro, small and medium enterprises (MSMEs) which were affected by the COVID-19 pandemic. However, the scheme for the distribution of the economic stimulus is considered complicated and slow [39]. Again, the issue revolves around complex bureaucracy within the 18 ministries that handle the MSMEs.

In contrast, malls, restaurants, and some entertainment sites have already opened since the PSBB was made to be less restricted even though economic recovery has to be implemented with a health paradigm in mind. The "new normal" term coined by the World Health Organization (WHO) is implementable only to the countries that are able to control the COVID-19 transmission. Indonesia, we argue, still falls short from this category. The situation in Indonesia is nowhere closer to the WHO's epidemiological, health system, and public health surveillance criteria, making the country still unfit to announce the new normal transition phase [40]. To implement the new normal, a government has to ensure that all the basic and primary health services and resources are well provided for, accessible, and affordable for all the citizens.

Nevertheless, the health and emergency system in Indonesia to handle COVID-19's patients are still in tatters without a sense of crisis. The system was ill prepared without prior clear designs to separate the hospitals that handle COVID-19 patients and regular patients. Oftentimes, many cases of death that occur are not caused by the COVID-19 virus, but due to a lack of adequate access to treatment[36]. Other than that, the ratio of beds is a standard measure whether or not the community's needs for health services are met [41]. Based on data on the ratio of beds to 1,000 residents in each country from the Organization for Economic Co-operation and Development (OECD) as of April 5, 2020[42], Indonesia is ranked 41 out of 42 countries, just barely meeting the standard set by the WHO which is 1 bed for 1,000 residents. Similarly, the COVID-19's specimen tests and capacities are still severely under the target set by the WHO which is 1,000:1 million citizens per week. If the total population of Indonesia is 260 million people, then a COVID-19 test of 260 thousand per week is needed. Thus, the test target per day is in the range of 37,000 in contrast to the new target set by the President which is 30,000 per day [43]. In reality, only around 14,000 or even much less tests have been conducted per day without any consistency and difficulty in obtaining clear data.

Health workers are also limited and overwhelmed by the surge of COVID and non-COVID patients daily. Based on data from the 2018 Indonesian Health Profile, there were 447,846 health workers (specialist doctors, doctors, and nursing personnel) spread throughout Indonesia [44]. The amount of health workers, especially doctors are sufficient in accordance with the WHO standards. However, the issue lies in the distribution of these workers which are still concentrated in big cities. There are six provinces with the fewest health workers - a percentage of less than 1 percent. The six are North Kalimantan, West Sulawesi, North Maluku, Gorontalo, West Papua, and Bangka Belitung Islands. Amongst these workers, many health workers have been confirmed to be positive for COVID-19, even resulting in several deaths. The main reasons seem to be a lack of personal protective equipment (APD) and patients' dishonesty when asked for their current state of health [41].

\section{Lessons Learned: Putting Vertical Coordination at the Spotlight}

Politicians and leaders across the world are experiencing the same kind of dilemma over public health safety and economic crises. No matter what, a sacrifice needs to be done albeit with inevitable consequences. Safeguarding the citizens should come first. However, containing the spread of the virus with lockdowns and self-isolation would never work if the national and regional policies are not coherent. Right from the early stage of the virus spread, the issues around policy discoordination within centralized measures of the COVID-19 response continue to exist.

It was found that the various proactive policies of local governments were caused by bureaucratic inaction at the central level. Real evidence can be seen from the dynamics of circulation instruction from the Ministry of Home Affairs (Kemendagri) number 443.1/2130/SJ regarding COVID-19 prevention which was delivered to all regional heads on March 4, 2020 [7]. The Director General of Regional Autonomy at the Ministry of Home Affairs on March 2, 2020 stated that the instruction cannot be forwarded to the regions because it is still waiting for time to coordinate with the Ministry of Health [45].

In addition, up until the $\mathrm{Q} 3$ of the disease spread, any strict and legally binding regional lockdown that limits people movement in and out their respective regions have not yet been in place. Initially, the central government through mandates set upon the President Joko Widodo forbid any local leaders from executing their own social restriction and health quarantine measures including territorial quarantines without prior authorization from the national government. However, at the same time he also stressed that public health comes first. He mandates, however, to implement partial PSBB within $\mathrm{RT} / \mathrm{RW}$ instead of a total PSBB [46].

Meanwhile, due to the surge of confirmed cases making the situation uncontrollable in DKI Jakarta Province, the Jakarta administration has issued Jakarta Governor Decree No. 959/2020 on the implementation of PSBB in the handling of COVID-19 in Jakarta. The decree stipulates the revoking of the governor's transitional PSBB policy in reverting to the PSBB policy based on Jakarta Governor Regulation No. 88/2020, which amends Governor Decree No. 33/2020 issued in April on the implementation of the PSBB policy. The PSBB status will last until September 27, 2020, and may be extended to October 11,2020, should there continuously be a significant rise in the number of COVID-19 infections [10]. This situation further illustrates the urgency for better communication and coordination across national and local governments with a mutual sense of crisis. Both the national and local governments have to set a like-minded goals and objectives with a health paradigm that focuses on flattening the curve before any economic restart and recovery could be attained 


\section{CONCLUSION}

COVID-19 pandemic has been causing large-scale loss of life and human suffering. The outbreak also has caused a nation-wide public health emergency as well as severe repercussion for economies across the country. In the midst of the double crisis caused by COVID-19 the government still struggles to determine which sectors (health or economy) should be prioritized first. This can be seen from ambivalent policy direction brought by the government such as the hesitation in implementing social restrictions policies and the relaxation of containment measures to open up the economy. System theory provides a useful model to analyze policy directions that seem to prioritize economics. As public policy conceived as a response or inputs of the political system to the demands from its environment, it can be said that the rugged act of balancing the health and economy with policy relaxation and economic recovery is a form or government response to seemingly profound public's demand of business reopening so they (the community) can regain their welfare back. As the fourth most populous country with limited institutional and financial capacity, one can argue that it will be rather difficult for Indonesia to provide social security for half of the population, let alone all of it. Furthermore, it is also worth mentioning that despite the high urgency to reopen the economy the handling of COVID-19 in Indonesia in term of capacity and effectiveness are still lacking. Testing quantity is fall short to WHO standard and inequality health access remain an issue. These conditions should encourage Indonesia Government to focus on improving its COVID-19 management, we should recognize that risking the lives of many does not lead to faster economic recovery as the economic and health are inextricably linked. Lastly, the pandemic has exposed the weakness of Indonesia's multilevel coordination which possibly has prevented the delivery of well-ordered and effective response, this should be taken as a lesson learned for Indonesia and it also shows the needs for streamlining integrated national programs that can eliminate slow bureaucratic processes.

\section{ACKNOWLEDGMENT}

This research entitled: Analysis of COVID-19 Policy Governance at the National and Regional level was funded by BP-PTNBH Kemenristek of Indonesia / BRIN 2020 research funding awarded to Dr. Saut Sagala. The authors received assistance from Dimas Mahardika and Erdianto Ammar for the data collection.

\section{REFERENCES}

[1] R. Nurfajriani, "Indonesian Corona Virus cases as of September 20 , 2020," Pikiran Rakyat, Sep. 2020.

[2] G. H. Cahya and M. I. Gorbiano, "Grim picture as Indonesia enters sixth month of COVID-19 outbreak - National - The Jakarta Post," Jakarta Post, Sep. 2020.

[3] A. Suryahadi, R. Al Izzati, and D. Suryadarma, "The Impact of COVID-19 Outbreak on Poverty: An Estimation for Indonesia (Draft)," SMERU Work. Pap., vol. April, pp. 1-20, 2020.

[4] R. Djalante et al., "Review and analysis of current responses to COVID-19 in Indonesia: Period of January to March 2020," Prog. Disaster Sci., vol. 6, no. SI: COVID-19 Special Collection, pp. 1-9, 2020, doi: 10.1016/j.pdisas.2020.100091.

[5] R. Djalante, R. Shaw, and A. DeWit, "Building resilience agains biological hazards and pandemics: COVID-19 and its implications for the Sendai Framework," Progress in Disaster Science. 2020, doi: 10.1016/j.pdisas.2020.100080.
[6] D. F. Rahman, "Economist, epidemiologist slam government over COVID-19 response - Business - The Jakarta Post," Jakarta Post, Aug. 2020.

[7] M. H. A. Dzakwan, "Memetakan kesiapan pemerintah daerah dalam menangani COVID-19 (Mapping Local Government Readiness in Handling COVID-19)," CSIS Comment., vol. 27, no. April, pp. 1-11, 2020.

[8] R. Puspasari, "Pemerintah pusat koordinasikan realokasi dan anggaran daerah untuk dukung penanganan COVID-19 (The central government coordinates reallocation and regional budgets to support the handling of Covid-19)," Kementerian Keuangan RI (Ministry of Finance of Republic of Indonesia), 2020.

[9] S. Susilawati, R. Falefi, and A. Purwoko, "Impact of COVID-19's Pandemic on the Economy of Indonesia," Budapest Int. Res. Critics Inst. Humanit. Soc. Sci., 2020, doi: 10.33258/birci.v3i2.954.

[10] EKONID, "COVID-19 developments in Indonesia," EKONID AHK, Sep. 2020.

[11] H. Whiteford and R. S. Weissman, "Key factors that influence government policies and decision making about healthcare priorities: Lessons for the field of eating disorders," International Journal of Eating Disorders. 2017, doi: 10.1002/eat.22688.

[12] R. Laxminarayan et al., "Advancement of global health: key messages from the Disease Control Priorities Project," Lancet, 2006, doi: 10.1016/S0140-6736(06)68440-7.

[13] P. Musgrove, "Public spending on health care: How are different criteria related?," Health Policy (New. York)., 1999, doi: 10.1016/S0168-8510(99)00024-X

[14] A. A. Anyebe, "An Overview of Approaches to the Study of Public Policy," Int. J. Polit. Sci., vol. 4, no. 1, pp. 8-17, 2018, doi: 10.20431/2454-9452.0401002.

[15] D. Hirschman and E. P. Berman, "Do economists make policies? On the political effects of economics," Socio-Economic Rev., 2014, doi: 10.1093/ser/mwu017.

[16] F. Muniesa, Y. Millo, and M. Callon, "An introduction to market devices," Sociol. Rev., vol. 55, no. 2, pp. 1-12, 2007, doi: 10.1111/j.1467-954X.2007.00727.x.

[17] G. M. Hodgson, "Economics and Systems Theory," J. Econ. Stud., vol. 14 , no. 4, pp. $65-86$, 1987 , doi: $10.1108 /$ eb002655.

[18] M. McKee and D. Stuckler, "If the world fails to protect the economy, COVID-19 will damage health not just now but also in the future," Nat. Med., vol. 26, pp. 640-648, 2020, doi: 10.1038/s41591-0200863-y.

[19] Z. Lin and C. Meissner, "Health vs. Wealth? Public Health Policies and the Economy During Covid-19," Natl. Bur. Econ. Res., 2020, doi: 10.3386/w27099.

[20] F. Firdaus, "Indonesia's zero Coronavirus cases may be bad screening," Foreign Policy, Feb. 2020.

[21] D. H. Setiamarga, “Jangan senang dulu walau negatif (Don't be happy yet even if you're tested negative)," Media Indonesia, Apr. 2020.

[22] Y. Mahendradata et al., "The Republic of Indonesia Health System Review. Health systems in transition. Vol-7, Number -1," World Health Organization, South East Asia Regional Office (SEARO). 2017.

[23] Humas Kemensetneg (Public Relations of Ministry of State Secretariat), "Arahan presiden terkait kebijakan pemerintah pusat dan daerah tangani COVID-19 (Presidential directives related to central and regional government policies to handle COVID-19)," Sekretariat Negara, Mar. 2020. .

[24] H. Andriani, S.Si, Apt, M.Sc, Ph.D, "Effectiveness of Large-Scale Social Restrictions (PSBB) toward the New Normal Era during COVID-19 Outbreak: a Mini Policy Review," J. Indones. Heal. Policy Adm., 2020, doi: 10.7454/ihpa.v5i2.4001.

[25] Databoks, “Konsumsi rumah tangga rendah, ekonomi kuartal II-2020 minus 5,32\% (Household comsumption is low, economy is the second quarter of 2020 minus 5,32\%)," Databoks, Aug. 2020.

[26] CNN Indonesia, "RI berkutat lawan Corona saat Thailand 100 hari nihil kasus (Republic of Indonesia struggles against Corona while Thailand 100 days with zero case)," CNN Indonesia, Sep. 2020. 
[27] CNN Indonesia, "Pedagang pasar demo tolak PSBB, Wali Kota Ambon bergeming (The market traders protest against PSBB, the Mayor of Ambon did not budge)," CNN Indonesia, Jul. 2020. .

[28] Tim Detikcom, “KSPI demo tolak RUU Cipta Kerja dan PHK dampak Corona di depan DPR besok (KSPI protests against the Omnibus Law and PHK Corona impact in front of DPR tomorrow)," Detik News, Aug. 2020. .

[29] D. Easton, "An Approach to the Analysis of Political Systems," World Polit., 1957, doi: 10.2307/2008920.

[30] N. Rayda, "Indonesia's economic stimulus not enough to stop layoffs, focus should be to contain COVID-19: Experts," CNA, Apr. 2020. .

[31] F. C. Farisa and ed. Krisiandi, "Survei SMRC: 87 persen responden nilai bansos Covid-19 hanya cukup untuk 2 pekan (SMRC Survey: 87 percent respondent think that the Covid-19 social assistance only sufficient for 2 weeks)," Kompas, May 2020. .

[32] M. Battaglini, "Public protests and policy making," Q. J. Econ., 2017, doi: 10.1093/qje/qjw039.

[33] G. A. Almond and S. Verba, The civic culture: Political attitudes and democracy in five nations. 2015.

[34] Sekretariat Negara (State Secretariat), "Presiden RI tentang progres realisasi program PEN klaster perlindungan sosial, 26 September 2020 (Indonesian President regarding the progress of the realization of the social protection cluster PEN program, 26 September 2020.)" Kementerian Sekretariat Negara RI (Ministry of State Secretariat of Republic of Indonesia), Jakarta, 2020.

[35] S. Ghosal, R. Bhattacharyya, and M. Majumder, "Impact of complete lockdown on total infection and death rates: A hierarchical cluster analysis," Diabetes Metab. Syndr. Clin. Res. Rev., 2020, doi: 10.1016/j.dsx.2020.05.026.

[36] P. E. Agus and E. Ova, "New Normal as a Middle Way ?:Health vs. Economic and Policy Alternatives in the COVID-19 Pandemic," in New Normal: Post-COVID-19 Socio-Economic and Political
Changes, M. Wawan and P. Winanti, Eds. Yogyakarta: Gajah Mada University, 2020.

[37] D. Milonakis and B. Fine, From political economy to economics: Method, the social and the historical in the evolution of economic theory. 2008.

[38] A. Case and A. Deaton, "Mortality and morbidity in the 21 st century," Brookings Pap. Econ. Act., 2017, doi: 10.1353/eca.2017.0005.

[39] BBC Indonesia, "COVID-19: Stimulus ekonomi berbelit dan penyaluran lamban, UMKM cemas bakal terpuruk - BBC News Indonesia (Covid-19: Economic stimulus is complicated and slow in distribution, SMEs might be hit hard - BBC News Indonesia)," $B B C$ Indonesia, Jul. 2020. .

[40] World Health Organization, "Public health criteria to adjust public health and social measures in the context of COVID-19 Annex to Considerations in adjusting public health and social measures in the context of COVID-19," 2020.

[41] S. Gerintya, "Seberapa siap fasilitas \& tenaga kesehatan RI hadapi COVID-19? (How ready is the health facility and human resources of Indonesia in facing the COVID-19?)," Tirto.id, Apr. 2020. .

[42] OECD Data, "Hospital Beds," OECD, Apr. 2020. .

[43] CNN Indonesia, "The Government's Corona specimen test target has not reached WHO standards," CNN Indonesia, Aug. 2020. .

[44] Kemenkes RI (Ministry of Health of Republic of Indonesia), "Profil kesehatan Indonesia 2018 (Indonesia's 2018 Health Profile) [Indonesia Health Profile 2018],” Jakarta, 2019.

[45] R. Wardy, "Dampak Corona, Kemdagri belum keluarkan imbauan ke daerah (Impact of Corona, Ministry of Home Affairs still not release instructions for regions yet)," Berita Satu, Mar. 2020. .

[46] Triaji, “Jokowi minta lockdown tingkat RT-RW, PSBB total Anies Baswedan batal? (Jokowi asks for lockdown in RT-RW, Anies Baswedan's total social restriction is cancelled?)," Bizlaw, Sep. 2020. 